\title{
Differential distribution of protein kinases along the crypt-to-lumen regions of rat colonic epithelium
}

\author{
B SCHWARTZ, G M FRASER, J LEVY, Y SHARONI, R GUBERMAN, \\ J KRAWIEC, AND S A LAMPRECHT \\ From the Gastroenterology and Endocrine Laboratories, Soroka Medical Center, and the Clinical \\ Biochemistry Unit, Ben-Gurion University of the Negev, Beer-Sheva, Israel
}

SUMMARY The activity of cAMP-dependent and cAMP-independent protein kinases, a class of enzymes involved in the regulation of cell proliferation was measured in rat colonic epithelium. Sequential cell populations harvested by a stepwise scraping technique from colonic crypt regions were identified by histology and incorporation of $\left[{ }^{3} \mathrm{H}\right]$-thymidine into DNA. CAMP-independent phosphorylation of casein, in the presence of $\left[\gamma^{32} \mathrm{P}\right] \mathrm{ATP}$, was markedly suppressed by quercetin, $\mathrm{a}$ bioflavonoid known to inhibit G-type casein kinase, protein kinase-C and tyrosine protein kinase. Conversely, the cyclic nucleotide regulatable form requiring histone as substrate was responsive to the action of the heat stable protein kinase inhibitor. The protein kinase species were characterised and partially purified by DEAE-cellulose chromatography. The activity of cAMP-dependent protein kinase in colonic cytosols (pmol ${ }^{32} \mathrm{P} / \mathrm{min} / \mathrm{mg}$ protein, means (SE)) increased from $129.4(15.9)$ in superficial cell populations to $238.5(31 \cdot 4)$ in lower crypt cell fractions $(p<0.01)$. Colonic cAMP. independent protein kinase activity increased from $87 \cdot 3(15 \cdot 6)$ in surface cell preparations to $178 \cdot 1$ $(30.0)$ in lower crypt cell populations $(\mathbf{p}<0.02)$. A comparable activity gradient was observed in membrane fractions. The activity gradient persisted when the results were expressed as a function of cellular DNA. These findings indicate that protein kinases display a defined topological segregation along the colonic crypt regions and that during migration to the lumen colonic cells attenuate enzyme signals supposedly related to tissue growth.

The colonic epithelium provides a unique model of cells at different stages of differentiation aligned in an orderly pattern along the crypt-lumen axis. ${ }^{12}$ Differentiation of colonic cells is accompanied by congruent morphological and biochemical changes. ${ }^{12}$ Synthesis of nucleic acids is restricted to mitotically active young cells in the crypt regions: during the migration toward the lumen, the maturing cells acquire the typical absorptive and secretory functions and limited life expectancy. ${ }^{12}$ Senescent colonocytes are shed into the bowel lumen and replaced by cells migrating from the proliferative zones. The sizes of the proliferative and functional compartments along the crypt surface axis are maintained within precise boundaries by multiple homoeostatic mechanisms. ${ }^{12}$

Address for correspondence: S A Lamprecht, PhD, Gastroenterology Laboratory, Soroka Medical Center, Beer-Sheva 84101, Israel.

Received for publication 3 March 1988.
In studies related to the molecular events involved in differentiation and growth of mammalian tissues, considerable interest has been focused on the biochemical profile and temporal expression of enzymes supposedly associated with cellular development. Many lines of evidence suggest that protein kinases are involved in the regulation of cell growth..$^{3-5} \mathrm{~A}$ salient example is provided by casein kinases, a class of ubiquitous enzymes which catalyse the phosphorylation of exogenous casein substrates. ${ }^{67}$ Thus, changes in the growth of rat mammary and uterine tissue ${ }^{9}$ are correlated with changes in the activity of casein kinases. Casein kinase activity markedly rises in regenerating rat liver after partial hepatectomy ${ }^{10}$ and after stimulation of murine lymphocytes with mitogens. ${ }^{11}$ Enhanced casein kinase activity is observed during mouse embryogenesis ${ }^{12}$; Sommercorn and $\mathrm{Krebs}^{13}$ have recently suggested that the kinase may contribute to the process of differentia- 
tion in mammalian cells. The casein kinase species are not stimulated by cyclic AMP, $\mathrm{Ca}^{2+}$-calmodulin or $\mathrm{Ca}^{2+}$-phospholipids. ${ }^{6-9} 14$ Molecular species are inhibited by quercetin,${ }^{89}{ }^{14} 15$ a bioflavonoid compound known to suppress the activity of protein kinase $C$ and tyrosine kinase in rat mammary gland, ${ }^{16}{ }^{17}$ as well as of tyrosine kinase associated with the oncogene product $\mathrm{pp} 60^{\mathrm{src}, 18}$ and with the receptor for epidermal growth factor. ${ }^{19}$

The participation of protein kinases in short term regulation of colonic transport and secretory events has been amply documented ${ }^{20-23}$; the question arises as to whether protein kinase activity is an integral part of the growth processes of colonic epithelia. The data hitherto available pertain to a possible regulatory role of cyclic nucleotides and of cyclic nucleotide dependent protein kinases in colonic cell proliferation..$^{2427}$ The aims of the present study were twofold: (i) to characterise colonic cAMP-independent protein kinases alongside the cAMP-responsive species, and (ii) to assess the crypt-to-lumen distribution of the enzymes involved in phosphorylation processes. The latter series of experiments was based on the reasonable premise that growth related protein kinases are mainly confined to the proliferative compartments of the large bowel epithelium. The colonic cAMP-independent protein kinases assayed in this study were operationally defined as casein kinases in view of their marked preference for acidic casein over basic histone as exogenous substrate. ${ }^{6}$

\section{Methods}

CHEMICALS AND BIOCHEMICALS

Methyl $\left[{ }^{3} \mathrm{H}\right]$ thymidine $(\mathrm{spec}$ act $5 \mathrm{Ci} / \mathrm{mmol})$ and $[\gamma$ ${ }^{32}$ P]ATP $(100 \mathrm{Ci} / \mathrm{mmol})$ were obtained from the Nuclear Research Center, Israel. Bovine milk casein, calf thymus histone IIA, sodium salt ATP and cAMP, theophylline, quercetin, polymerised calf thymus DNA, bovine serum albumin, DL-dithiothreitol and DEAE-cellulose were purchased from Sigma Chemical Co, St Louis, MO, USA. All reagents were of analytical grade.

TISSUE PREPARATION AND COLLECTION OF CELL FRACTIONS

Adult male Charles River rats (200-250 g) were fed standard laboratory Purine Chow diet and tap water ad libitum. The animals were killed by cervical dislocation, the colon quickly excised and immersed in ice cold $0.9 \% \mathrm{NaCl}$. The large bowel was slit longitudinally along the mesenteric border and the luminal contents flushed out with cold saline. The cleansed colon was flattened on to filter paper with the mucosal surface upwards, and kept moistened with cold $0.9 \% \mathrm{NaCl}$.
The sequential scraping technique of Dietschy and Siperstein ${ }^{28}$ was used to harvest from whole colonic mucosa relatively homogeneous cell populations along the crypt-lumen axis. Briefly, light scraping of the mucosa with a blunt edged glass microscope slide removed most of the superficial epithelial layer (surface cell preparation). Additional scraping yielded the middle crypt cell fraction. The last scraping removed the remaining mucosal layer enriched in lower crypt proliferative cell populations. Each fraction was quickly weighted and 5 volumes of buffer containing $20 \mathrm{mM}$ Tris- $\mathrm{HCl}, \mathrm{pH} 7.5,0.25 \mathrm{mM}$ sucrose, $2 \mathrm{mM} \mathrm{MgCl}, 1 \mathrm{mM} \mathrm{CaCl} 2,10 \mathrm{mM} \mathrm{KCl}$ (Tris-sucrose buffer) were added.

Samples of intestinal tissue before and after each sequential scraping were collected for histological examination. The tissues were fixed in neutral buffered formalin, dehydrated in increasing concentrations of alcohol and embedded in paraffin. Sections of properly oriented tissue were cut to $6 \mu \mathrm{m}$ thickness, stained with haematoxylin and eosin, and examined microscopically.

METHYL [ $\left.{ }^{3} \mathrm{H}\right]$-THYMIDINE INCORPORATION INTO COLONIC DNA

One hour before death tritiated thymidine $(100 \mu \mathrm{Ci})$ was administered ip to a number of rats. Mucosal cell fractions from colon were collected as previously described, and DNA extraction was performed according to Johnson and Guthrie. ${ }^{29}$ The weighed samples were homogenised in $1 \mathrm{ml}$ vol $0.2 \mathrm{~N}$ perchloric acid and centrifuged for 10 minutes at $800 \mathrm{~g}$. The precipitate was dissolved in $4 \mathrm{ml} 10 \%$ perchloric acid, heated in a boiling water bath for 10 minutes and centrifuged at $500 \mathrm{~g}$ for 20 minutes to remove denatured protein. Incorporation of $\left[{ }^{3} \mathrm{H}\right]$ thymidine into colonic DNA was assayed by counting aliquots of the supernatant in a Packard liquid scintillation counter, and results expressed as $\mathrm{cpm} / \mu \mathrm{g}$ DNA.

\section{PREPARATION OF COLONIC MEMBRANES AND} CYTOSOLS

Soluble and particulate fractions from harvested cell populations were prepared as described by Sharoni $e t$ al. ${ }^{89}$ Briefly, the colonic tissue fractions in Trissucrose buffer were homogenised using a Polytron PT-10 homogeniser (Kinematica, GmbH, CU-6010, Kriens-Lucern, Switzerland) at setting 4 for two periods of 10 seconds with a time interval of 20 seconds for cooling purposes. The homogenate was centrifuged at $800 \mathrm{~g}$ for 10 minutes to remove unbroken cells and nuclear debris. The resultant supernatant was spun at $100000 \mathrm{~g}$ for 60 minutes to prepare the soluble fraction (cytosol) and to pellet a crude membrane preparation. The particulate fraction was resuspended in ,Tris-sucrose buffer. 
DEAE-CELLULOSE CHROMATOGRAPHY OF

COLONIC CYTOSOLS

DEAE-cellulose was equilibrated with $20 \mathrm{mM}$ Tris$\mathrm{HCl}$ buffer, pH 7.5 containing $1 \mathrm{mM}$ dithiothreitol. Cytosols derived from colonic fractions enriched in lower crypt cell populations were adsorbed to the DEAE-cellulose and the slurry introduced on to a column at $4^{\circ} \mathrm{C}$. The column was washed with $100 \mathrm{ml}$ Tris- $\mathrm{HCl}$ buffer and then eluted with a linear gradient of $\mathrm{KCl}(0-0.5 \mathrm{M})$. An aliquot of each collected fraction was monitored for protein content (absorbance at $280 \mathrm{~nm}$ ) and assayed for cAMP-dependent and independent protein kinase activities.

PREPARATION OF HEAT STABLE PROTEIN KINASE INHIBITOR

Heat stable, cAMP-dependent protein kinase inhibitor protein was prepared from bovine skeletal muscle by the method of McPherson et $\mathrm{al}^{30}$ up to the DEAE-cellulose purification step.

PROTEIN KINASE ASSAYS

Protein kinase activity of colonic crude membrane preparations, whole cytosols and DEAE-cellulose cytosolic fractions was determined according to Sharoni et al. ${ }^{89}$ The cAMP-dependent protein kinase assay was based on the enzymatic transfer of ${ }^{32} \mathrm{P}$ from $\left[\gamma-{ }^{32} \mathrm{P}\right] \mathrm{ATP}$ into histone in the presence of cAMP $(5$ $\mu \mathrm{M})$. The values of ${ }^{32} \mathrm{P}$ incorporation into histone observed in the absence of the cyclic nucleotide were subtracted to obtain the activity dependent on cAMP. Some assay mixtures contained the protein kinase inhibitor, added in an amount equivalent to $10 \mu \mathrm{g}$ protein.

The cAMP-independent protein kinase assay was based on the incorporation of ${ }^{32} \mathrm{P}$ from labelled ATP into casein in the absence or in the presence of 0.1 $\mathrm{mM}$ quercetin dissolved in $60 \%$ dimethyl sulfoxide. The final concentration of the solvent in the assay was $3 \%$. The difference between the respective values represents the quercetin-inhibitable, cAMP-independent protein kinase activity.

The standard assay mixture in a final volume of 150 $\mu l$ contained $20 \mathrm{mM}$ or $50 \mathrm{mM}$ potassium phosphate buffer ( $\mathrm{pH}$ 6.5) for the cAMP-dependent and independent protein kinase respectively; $10 \mathrm{mM}$ magnesium acetate, $1 \mathrm{mM}$ theophylline, $0.45 \mathrm{mg}$ casein or histone and $40 \mu \mathrm{g}$ colonic protein. A reaction mixture containing all the assay components was immediately processed before incubation and utilised as a blank. Phosphorylation was started by the addition of $50 \mu \mathrm{M}$ ATP together with 1$2 \mu \mathrm{Ci}\left[\gamma^{-32} \mathrm{P}\right] \mathrm{ATP}$. The incubation was carried out at $30^{\circ} \mathrm{C}$ in a shaking water bath for 10 minutes. All assays were carried out in duplicate. Under the assay conditions used the amount of ${ }^{32} \mathrm{P}$ incorporated into the appropriate exogenous substrates was linear with respect to time and protein concentrations. The reaction was terminated by withdrawing a $100 \mu \mathrm{l}$ aliquot from the incubation mixture and spotting the reaction products on filter paper discs $(2.4 \mathrm{~cm}$, Whatman $3 \mathrm{MM}$, Whatman Inc, Clifton, NJ). The filter discs were immediately immersed in ice cold $5 \%$ trichloroacetic acid solution, washed several times and soaked overnight in acid with gentle shaking. TCA was removed by rinsing the discs in $95 \%$ ethanol; the filters were dried at room temperature and the radioactivity measured by liquid scintillation spectrometry.

PROTEIN AND DNA DETERMINATION

Protein content was determined according to the method of Lowry et $a l^{31}$ using crystalline bovine serum albumin as a standard.

DNA content was assessed according to the diphenylamine method of Burton ${ }^{32}$ using calf thymus DNA as a standard.

STATISTICAL ANALYSIS

Values are given as the mean (SE) of at least four determinations. Significance of difference between samples was evaluated using Student's $t$ test. Statistical significance was assigned when $\mathrm{p}<0.05$.

\section{Results}

HISTOLOGY OF COLONIC CELL FRACTIONS AND IN VIVO INCORPORATION OF [ $\left.{ }^{3} \mathrm{H}\right]$-THYMIDINE INTO DNA

Three cell fractions were harvested from rat colon by the stepwise scraping technique and their anatomical relationship to crypt and lumen was assessed by light microscopy. The histological findings showed that the first fraction included mostly upper crypt surface cells, the second cell preparation was enriched with middle crypt cells, and the last fraction consisted of lower crypt cells. Submucosal tissue was not included in the isolated material. In the present study we have omitted the transitional, middle crypt cell prepara-

Table 1 In vivo incorporation of $\left[{ }^{3} \mathrm{H}\right]$-thymidine into cell populations of rat colonic epithelium

\begin{tabular}{ll}
\hline Region & $\begin{array}{l}{\left[{ }^{3} \mathrm{H}\right] \text {-thymidine incorporation }} \\
(c p m / \mu g D N A)\end{array}$ \\
\hline Surface cells & $3877(806)$ \\
Lower crypt cells & $8847(282)$ \\
\hline
\end{tabular}

[ ${ }^{3} \mathrm{H}$-methyl]-thymidine was administered ip to a group of rats and incorporation of the labelled nucleoside into DNA was measured one hour later. Colonic mucosal fractions consisting of cells at different stages of differentiation were harvested by a stepwise scraping technique. 
tions in order to minimise admixture of cell types and to compare surface, non-proliferative colonic cell populations with cell fractions harvested from the deeper portions of the colonic crypts that exhibit the highest proliferative activity. ${ }^{12}$

Incorporation of $\left[{ }^{3} \mathrm{H}\right]$-thymidine into colonic DNA epithelial populations showed a significant increase from surface cells to cells harbouring the lower crypt regions (Table 1). Thus, incorporation of the labelled nucleoside into DNA of proliferative cell fractions harvested from lower crypt regions (cpm/ $\mu \mathrm{g}$ DNA, 8847 (282)) was significantly higher compared with thymidine incorporation values measured in surface cell preparations $(3877(806))$.

\section{CHARACTERISATION OF COLONIC PROTEIN}

KINASE ACTIVITIES

Protein kinase activities were measured in cytosolic preparations from colonic lower crypt fractions in the presence of either casein or histone. Incorporation of $\left.{ }^{32} \mathrm{P}\right]$ from labelled ATP into acceptor casein substrate was unaffected by the presence of $5 \mu \mathrm{M}$
cAMP (Fig. 1a), a finding consistent with the notion that casein kinases are cyclic nucleotide-independent protein kinase species. The bioflavonoid quercetin proved to be a potent inhibitor of casein kinase activity in a concentration-dependent manner (Fig. 1a): $10^{-4}$ M quercetin brought about marked inhibition $(70 \%)$ of casein phosphorylation.

Cyclic AMP-dependent protein kinase activity was tested with exogenous histone: a two-fold increase in the transfer of $\left.{ }^{32} \mathrm{P}\right]$ into the acceptor protein was observed in the presence of $5 \mu \mathrm{M}$ cAMP (Fig. 1b). Likewise for the casein kinase species, the 'basal' enzyme activity - namely, in the absence of exogenous cAMP-was drastically curtailed by quercetin (Fig. 1b). Deduction of the basal residual kinase activities from the corresponding activities measured in the presence of cAMP shows that, at each quercetin concentration, the magnitude of cAMP-stimulated histone phosphorylation remained constant (dotted line, Fig. 1b). This constancy in activity signifies that histone kinase activity stimulated by the cyclic nucleotide is unaffected by quercetin concentrations
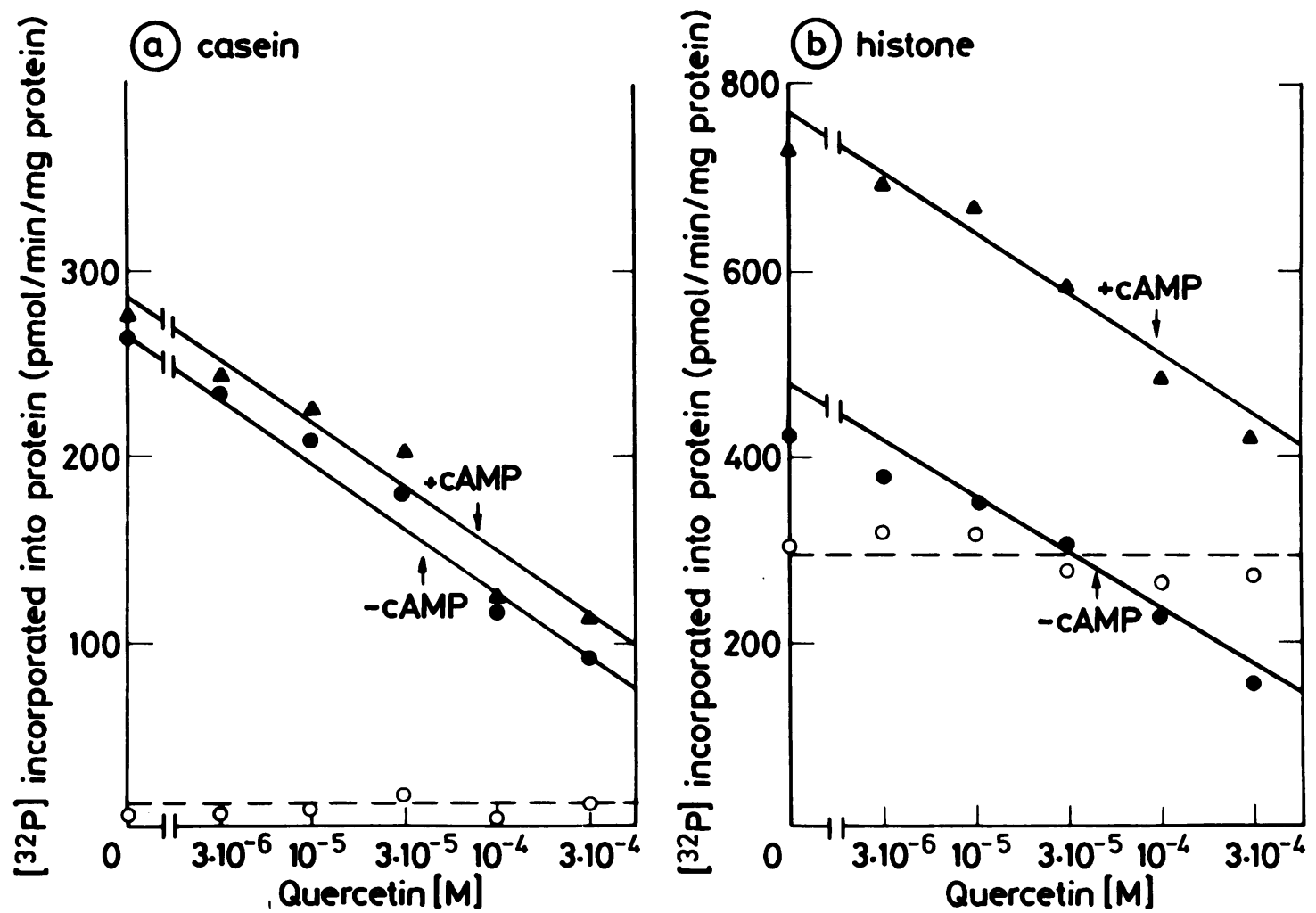

Fig. 1 Effect of quercetin on PK activity of colonic cytosols derived from lower crypt cell populations. Phosphorylation of either casein $(A)$ or histone $(B)$ was assayed in the absence $(O)$ or presence $(\triangle)$ of $5 \mu M c A M P$. (O) cAMP-stimulated PK activity expressed as the difference between $P K$ activities in the presence or absence of $5 \mu M c A M P$. PK: protein kinase. 
which drastically curtail the activity of cAMP independent kinase species (Fig. 1a). This selective inhibitory property of quercetin allowed us to use the bioflavonoid as a tool for the biochemical characterisation of cAMP-independent protein kinase forms in colonic preparations.

PROTEIN KINASE ACTIVITIES IN DEAE-

CELLULOSE CHROMATOGRAPHY FRACTIONS

DEAE-cellulose chromatography of crude cytosols derived from colonic lower crypt cell preparations resulted in major peaks exhibiting protein kinase activities (Fig. 2). The early peak I eluted with $0 \cdot 15$ $\mathrm{mM} \mathrm{KCl}$, contained protein kinase activity stimulated by cAMP but unresponsive to quercetin $\left(10^{-4} \mathrm{M}\right)$ (Fig. 2a). The elution profile of casein kinase activity was resolved into two peaks (Fig. 2b). The most retarded peak, peak III, eluted at around $0.4 \mathrm{mM} / 1$ $\mathrm{KCl}$, included quercetin (mM) inhibitable, cAMPindependent casein kinase activity. Peak II, sharing a broad shoulder with peak I, exhibited casein kinase activity which, however, was feebly responsive to quercetin $\left(10^{-4} \mathrm{M}\right)$ (Fig. 2b).

The effect of the heat-stable protein inhibitor, specifically acting on the catalytic subunit of cAMPdependent protein kinases, was tested on fractions contained within peaks I and III (Fig. 2, inset). Protein kinase inhibitor drastically reduced basal histone phosphorylation and prevented cAMP stimulation of the kinase enzyme eluted with peak I, providing persuasive evidence that the bulk of kinase activity contained in the early peak is provided by cAMP-dependent kinase species. Casein phosphorylation in peak III was unaffected by PKI: the feeble histone phosphorylation exhibited by pooled fractions from peak III (inset, Fig. 2) proved to be unresponsive to PKI inhibitory action.

PROTEIN KINASE IN CYTOSOLIC AND

PARTICULATE PREPARATIONS FROM CELL POPULATIONS ALONG THE LUMEN-CRYPT AXIS Crude cytosolic and particulate preparations derived

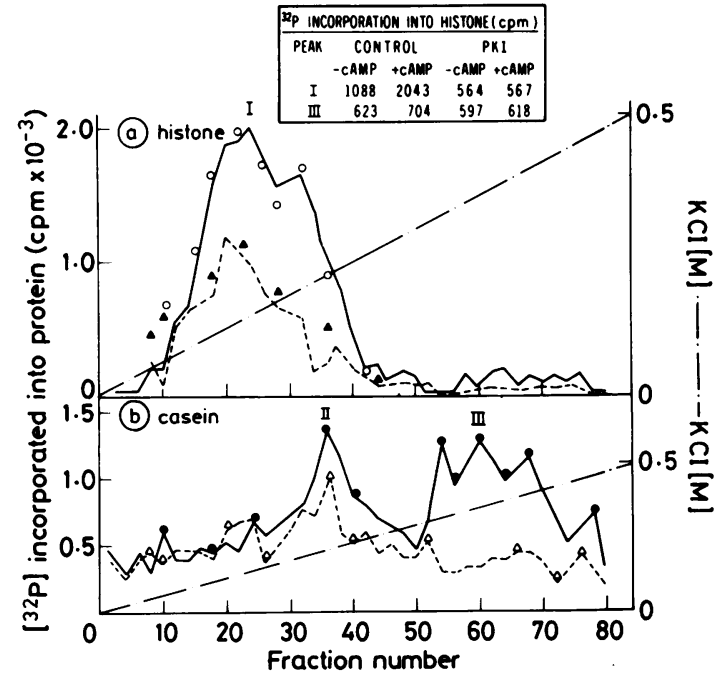

Fig. 2 DEAE-cellulose chromatography of colonic cytosols derived from lower crypt populations. The elution profile denotes $P K$ activity. $P K$ : protein kinase; $P K I$ : protein kinase inhibitor. A. cAMP-dependent PK activity (peak I) assayed with histone as substrate: $(\mathbf{\Delta})$ - in the absence of $c A M P ;(\bigcirc)$ - in the presence of $5 \mu M c A M P$. The inset shows the inhibitory action of PKI on basal and stimulated enzyme activity. $10 \mu \mathrm{g}$ protein of the partially purified $P K I$ preparation was added to incubation tubes. Histone phosphorylation was unaffected by $10^{+4} \mathrm{M}$ quercetin (not shown). B. cAMP-independent PK activity (peaks II and III) with casein as substrate in the absence (O) and presence $(\triangle)$ of $10^{+4} M$ quercetin. The earlier peak (II) eluted between fractions $30-40$ denotes casein PK activity that is feebly responsive to quercetin. The cAMP-independent, quercetininhibitable PK form is unresponsive to PKI (inset).

from cell populations collected along the colonic surface-crypt axis were analysed for cAMP-dependent and-independent protein kinase activities as defined previously.

Differential distribution in the activities of both protein kinase classes was noted along the cryptsurface regions (Table 2). Thus the incorporation of

Table 2 Activity of protein kinases in cytosolic and membrane cell preparations from rat colonic epithelium

\begin{tabular}{|c|c|c|c|c|}
\hline \multirow[b]{4}{*}{ Region } & \multicolumn{4}{|c|}{ Pmol ${ }^{32} \mathrm{P}$ incorporated $/ \mathrm{min} / \mathrm{mg}$ protein $(a)$ or $\mu g$ DNA $(b)$} \\
\hline & \multirow{3}{*}{$\begin{array}{l}\text { cAMP-dependent } P K \\
\text { Cytosol } \\
\text { (a) }\end{array}$} & \multicolumn{2}{|c|}{ cAMP-independent $P K$} & \multirow{3}{*}{$\frac{\text { Membrane }}{\text { (a) }}$} \\
\hline & & \multicolumn{2}{|l|}{ Cytosol } & \\
\hline & & (a) & (b) & \\
\hline $\begin{array}{l}\text { Surface cells } \\
\text { Lower crypt cells }\end{array}$ & $\begin{array}{l}129.4(15.9) \\
238.5(31.4) \dagger\end{array}$ & $\begin{array}{c}87 \cdot 3(15 \cdot 6) \\
178 \cdot 1(30 \cdot 0) \ddagger\end{array}$ & $\begin{array}{l}1 \cdot 6(0 \cdot 4) \\
4 \cdot 0(0 \cdot 3)^{*}\end{array}$ & $\begin{array}{l}236 \cdot 1(26 \cdot 4) \\
401 \cdot 4(66 \cdot 4) \S\end{array}$ \\
\hline
\end{tabular}

Results are expressed as mean (SE) of eight separate experiments. All assays within individual experiments were done in duplicate. ${ }^{*} \mathrm{p}<0.001 ; \nmid \mathrm{p}<0.01 ; \neq \mathrm{p}<0.02 ; \S \mathrm{p}<0.05$. Lower crypt cell values compared to surface cell values. cAMP-dependent PK activity in membrane preparations was negligible. PK: protein kinase. 
[ $\left.{ }^{32} \mathrm{P}\right]$ by the cyclic nucleotide-dependent protein kinases into TCA-extractable protein ( $\mathrm{pmol}{ }^{32} \mathrm{P} / \mathrm{min} /$ $\mathrm{mg}$ protein) was $129.4(15.9)$ in the surface cell preparations compared to $238.5(31.4)$ in lower crypt fractions $(p<0 \cdot 01)$. A similar activity gradient was exhibited by quercetin inhibitable, cyclic AMPindependent protein kinases. $\left[{ }^{32} \mathrm{P}\right]$ incorporation values were $87.3(15.6)$ in the surface cell fractions versus $179.1(30.0)$ in the lower crypt regions $(\mathrm{p}<0 \cdot 02)$. Likewise for soluble protein kinase species, the activity of particulate cAMP-independent protein kinases was two-fold higher $(p<0.05)$ in lower crypt cell fractions compared with surface cell preparations. As illustrated in Table 2, the activity gradient persisted whether results were expressed per milligram of mucosal protein or as a function of cellular DNA. The activity of the particulate enzyme in the cell preparations collected along the surfacecrypt axis was higher than that measured in the cytosolic counterpart.

\section{Discussion}

Implicit in the process of intestinal cell differentiation and maturation is the notion that enzyme activities related to stimulation of tissue growth are restricted to the proliferative compartments of intestinal epithelia. We have therefore harvested from rat colon relatively homogeneous mucosal cell populations at different developmental stages and assessed the activities of cyclic nucleotide-dependent and independent protein kinases, enzyme species involved in the regulation of cell proliferation..$^{8-14}$ The effectiveness and reproducibility of the scraping technique - a non-aggressive method for collecting colonic cell populations along the crypt-lumen regions - was shown by morphological criteria and by the distribution of cells in S-phase pulse-labelled in vivo with tritiated thymidine.

The activity of cAMP-dependent and independent protein kinases in colonic particulate and cytosolic fractions and in cytosolic preparations partially purified by DEAE-cellulose chromatography was determined using preferential substrates and selective modulators. The chromatographic separation procedure yielded at least three protein kinase activities. cAMP-regulatable activity, eluted from the DEAE-cellulose column as a single broad peak, was highly responsive to the heat stable protein kinase inhibitor protein. Quercetin did not impede histone phosphorylation by cAMP-dependent protein kinase forms. Two distinct colonic casein kinase activities were eluted at different $\mathrm{KCl}$ concentrations, a finding in agreement with the chromatographic profile of casein kinases in a variety of tissues. $^{8334}$ Phosphorylation of casein by colonic
cAMP-independent protein kinase species contained in peak III removed at higher salt concentration was markedly suppressed by quercetin. In contrast, the peak eluted at lower $\mathrm{KCl}$ concentration containing casein kinase activity was unresponsive to quercetin. Casein kinase molecular forms unresponsive to quercetin have also been found in rat mammary gland cytosols eluted from DEAE-cellulose chromatography ${ }^{8}$ and in the partially purified soluble preparations from bovine adrenal cortex.$^{15}$ Cochet $e t$ al ${ }^{15}$ reported that the bioflavonoid inhibits the G-type casein kinase but has no effect on the A-type casein kinase form. It is well recognised that compounds that inhibit the type $G$ enzyme are ineffective on the type A form. ${ }^{6}$

Rat colonic protein kinases displayed a diminishing activity gradient from crypt-to-surface areas with the bulk of the activity confined to the lower crypt zones - namely, in the proliferative compartment (Table 2). A similar distribution profile has recently been observed in normal human colonic epithelium (unpublished observation). It would seem, therefore, that during the ascent to the gut lumen the maturing colonocytes attenuate enzyme activities related to proliferative events.

A positional activity profile similar to that observed for the casein kinases is exhibited by colonic ornithine decarboxylase, ${ }^{35}$ an enzyme involved in the regulation of intestinal growth processes. ${ }^{367}{ }^{37}$ Interestingly, Mezzetti and coworkers ${ }^{38}$ have recently reported that polyamines may serve as specific regulatory factors capable of stimulating chick intestine cyclic nucleotide independent casein kinases. Polycations such as the naturally occurring polyamines have previously been shown to activate casein kinases. ${ }^{6}$

The notion of a possible functional relationship between cyclic AMP-independent, quercetin inhibitable protein kinase activity and colonic proliferative processes is supported by previous studies related to casein kinase behaviour in growing mammalian tissues. Thus, a close correlation was found between the magnitude of quercetin-responsive protein kinase activity and proliferative stages in rat mammary gland and uterine tissue. ${ }^{89}$

Cytosolic cAMP-dependent protein kinases exhibit a differential activity along the colonic epithelium akin to that observed for the cyclic nucleotide independent kinase species (Table 2). The cyclic AMP system has been implicated in the inhibitory regulation of growth control in a variety of cells ${ }^{39-11}$; changes in intracellular concentration of cAMP, possibly acting through the specific responsive protein kinases, may thus serve as a negative signal to cell proliferative activity. It may therefore be that the cyclic AMP system controls the size of colonic epithelial com- 
partments by exerting a restraining action on cell proliferation along the colonic crypt axis. ${ }^{24-27}$ In this context it is relevant to note that cellular growth is closely regulated by opposing stimulatory and inhibitory signals.

The question arises whether the cAMP system, in concert with positive signals, regulates proliferative activities of colonic cells harboring the crypt regions or whether local homoeostatic mechanisms maintain low cAMP concentrations in colonic proliferative zones, conceivably allowing the restraining action of the cAMP system on growth-related processes to impinge on maturing cells leaving the proliferative compartment.

The latter mechanistic view is supported by a recent extensive study of cAMP metabolism in rat colonic epithelial cells with different proliferative activities. ${ }^{25}$ The following observations were made: (i) The basal cAMP content was lower in cell populations harvested from colonic crypt zones compared with superficial cells; (ii) the reduction in endogenous cAMP content was consequently associated with a decrease in basal cAMP-dependent protein kinase activity in proliferative cells. By contrast, (iii) cyclic nucleotide phosphodiesterase activity was shown to be markedly higher in cells collected from colonic crypt regions with respect to luminal cell preparations.

It has therefore been proposed that a reduced cAMP content may be a determinant of the brisk proliferative activity of colonic cells restricted to low crypt areas. A salient role is thus envisaged for enzyme controlled rates of cAMP turnover in the regulation of growth processes along the colonic crypt-lumen axis.

These interesting results are not at variance with the findings presented in this paper showing that cAMP-dependent protein kinase activity is higher in colonic cell populations harvested from the lower crypt regions (Table 2). Determination of the enzyme activity was performed by us in the presence of either a phosphodiesterase inhibitor and exogenous cAMP or in cell preparations containing the inhibitor on its own, viz. not under the strict steady-state basal conditions described by Craven and DeRubertis. ${ }^{25}$ Our results support the notion that the low basal activity of the kinase system in colonic proliferating cells is not attributable to enzyme deficiency.

It could be argued that considerable residual protein kinase activity is detectable in the upper surface colonic epithelial cell zone, the exclusive preserve of differentiated, mature colonocytes, and therefore part of the enzyme activity may derive from unavoidable admixture of cells resident in the transitional zone of colonic epithelium which possess casein kinase activity (data not shown). Notwith- standing this possibility, it might be said that phosphorylation of specific cellular endogenous substrates is a pleiotropic event related not only to regulation of tissue growth but also to short-term episodes in cell metabolism. We therefore favour the concept that the bulk of the phosphorylation activity present in the surface regions of colonic epithelium is an integral part of the biochemical profile of differentiated colonic cells and thus expresses metabolic events typical of the mature colonocyte, such as mucus formation, ion transport, absorption and secretion. ${ }^{21-23}$

Preferential segregation of growth-related protein kinase species in defined regions of colonic epithelium is consistent with the notion that the size of the proliferative compartment is maintained within boundaries by precise homoeostatic mechanisms. ${ }^{12}$ Lipkin and coworkers have shown an expansion of the proliferative zone in rodents exposed to the carcinogen DMH and in colon cancer prone humans. ${ }^{42}{ }^{43}$ Thus, misguided colonic cells retain the capacity to synthesise DNA throughout their life span and populate normally forbidden domains of the colonic epithelium. The intriguing question therefore arises as to whether the aberrant biochemical capability of these cells is expressed by an abnormal positional shift in the crypt-to-lumen distribution of protein kinase species supposedly related to intestinal proliferative events. Indeed, preliminary experiments have shown a significant expansion of the activity grádient of colonic casein protein kinases in mucosa of DMH-treated rats in the absence of frank neoplasia. ${ }^{44}$ Sharoni et $a l^{14}$ have shown that quercetin-inhibitable, cAMP-independent protein kinase activity is closely correlated with the growth of DMBA-induced rat mammary tumours. In this context it is worth noting that high casein kinase activity, compared with control tissues, was found in leukaemic cells, ${ }^{45} 46$ in tumour cell cultures, ${ }^{47}$ in rapidly proliferating mouse tumour cells ${ }^{12}$ and in colonic tumour tissue derived from DHM-treated rats. ${ }^{44}$

In addition to casein kinases, examples of kinase enzymes that show an increase in activity during cell proliferation and transformation include tyrosine specific kinase species. ${ }^{4849}$ These protein kinase activities have been found to be associated with membrane receptors for a variety of growth factors. ${ }^{50}$ Interest in the molecular basis of the growth promoting action of protein kinases has been fostered by the recurring observation that the transforming gene products of several RNA tumour viruses possess or are associated with cyclic nucleotide independent phosphorylating activity. ${ }^{4849}$ While substantial information, albeit controversial, is available on the possible involvement of cyclic nucleotide dependent protein kinases in normal growth and neoplastic 
processes ${ }^{24-26}$ the precise biochemical significance of casein kinase isozymes able to phosphorylate a large spectrum of endogenous substrates ${ }^{6152}$ remains to be determined. Evidence is accruing to support the concept that casein kinase activity may be intimately involved in the positive modulation of tissue growth. Indeed, the distribution of the kinases along the crypt regions of colonic epithelium reported in this study is what one would predict if the cyclic nucleotide independent enzyme activity were an important biochemical concomitant of colonic cell proliferation.

\section{Addendum}

Craven and DeRubertis (Cancer Res 1987; 47: 3434 8 ) have shown a higher particulate protein kinase $C$ activity in proliferative colonic epithelial cells compared to nonproliferative superficial cells. Likewise for the casein kinase species (this study), the authors support a role for protein kinase $\mathrm{C}$ in the positive control of colonic epithelial proliferation.

This work was supported by a grant from the Israeli Academy of Sciences and Humanities. The authors are grateful to Mrs M Duman for her skilful and devoted editorial assistance. Part of this paper was presented in abstract form at the World Congresses of Gastroenterology, San Paolo, Brazil, 1986 [Abstract]. (Dig Dis Sci 1986, 31: 168S, A622.)

\section{References}

1 Williamson RCN. Intestinal adaptation. $N$ Engl J Med 1978; 298: 1393-1402, 1444-50.

2 Lipkin M. Growth and development of gastrointestinal cells. Ann Rev Physiol 1985; 47: 173-97.

3 Martin GS, Radke K, Carter C, Moss P, Dehazya P, Gilmore $\mathrm{T}$. The role of protein phosphorylation at tyrosine in transformation and mitogenesis. In: Vande Woude GF, Levine AJ, Topp WC, Watson JD, eds. Cancer cells. Cold Spring Harbor, New York: Cold Spring Harbor Laboratory Publications, 1984; 2: 89-97.

4 Foulkes JG, Rosner MR. Tyrosine-specific protein kinases as mediators of growth control. In: Cohen P, Housley MD, eds. Molecular mechanisms of transmembrane signalling. New York: Elsevier, 1985.

5 Schwantke N, Le Bouffant F, Doree M, Le Peuch CJ. Protein kinase C: properties and possible role in cellular division and differentiation. Biochimie 1985; 67: 110310.

6 Hathaway GM, Traugh JA. Casein kinases - multipotential protein kinases. Curr Top Cell Regul 1982; 21: 101-27.

7 Meggio F, Agostinis P, Pinna LA. Casein kinases and their protein substrates in rat liver cytosol: evidence for their participation in multimolecular systems. Biochim Biophys Acta 1985; 846: 248-56.

8 Sharoni Y, Feldman B, Teuerstein I, Levy J. Protein kinase activity in the rat mammary gland during pregnancy, lactation and weaning: a correlation with growth but not with progesterone receptor levels. Endocrinology 1984; 115: 1918-24.

9 Sharoni Y, Teuerstein I, Shirman A, Feldman B, Levy J. Cyclic changes in rat uterine proliferation during the estrous cycle are preceded by changes in protein kinase activity. Endrocrinology 1984; 115: 2297-302.

10 Ballal NR, Kang Y-J, Olson MOJ, Busch H. Changes in nucleolar proteins and their phosphorylation patterns during liver regeneration. J Biol Chem 1975; 250: 5921-5.

11 Geahlen RL, Harrison ML. Induction of a substrate for casein kinase II during lymphocyte mitogenesis. Biochim Biophys Acta 1984; 804: 169-75.

12 Schneider R, Reichert GH, Issinger O-G. Enhanced casein kinase II activity during mouse embryogenesis. Eur J Biochem 1986; 161: 733-8.

13 Sommercorn J, Krebs EG. Induction of casein kinase II during differentiation of 3T3-L1 cells. J Biol Chem 1987; 262: 3839-43.

14 Sharoni Y, Graziani Y, Karny N, Feldman B, Levy J. cAMP-independent protein kinase activity is correlated with growth of rat mammary tumours. Eur J Cancer Clin Oncol 1984; 20: 277-81.

15 Cochet C, Feige JJ, Pirollet F, Keramidas M, Chambaz EM. Selective inhibition of a cyclic nucleotide protein kinase ( $G$ type casein kinase) by quercetin and related polyphenols. Biochem Pharmacol 1982; 31: 1357-61.

16 Caulfield JJ, Bolander FF. Involvement of protein kinase $C$ in mouse mammary gland development. $J$ Endocrinol 1986; 109: 29-34.

17 Levy J, Teuerstein I, Marbach M, Radian S, Sharoni Y. Tyrosine protein kinase activity in the DMBA-induced rat mammary tumor: inhibition by quercetin. Biochem Biophys Res Commun 1984; 123: 1227-33.

18 Graziani Y, Erikson E, Erikson RL. The effect of quercetin on the phosphorylation activity of Rous sarcoma virus transforming gene product in vitro and in vivo. Eur J Biochem 1983; 135: 583-9.

19 Akiyama T, Ishida J, Nakagawa S, et al. Genistein, a specific inhibitor of tyrosine-specific protein kinases. J Biol Chem 1987; 262: 5592-5.

20 Donowitz M, Cheng HY, Sharp GWG. Effects of phorbol esters on sodium and chloride transport in rat colon. Am J Physiol 1986; 251: G509-17.

21 Fondacaro JD. Intestinal ion transport and diarrhoeal disease. Am J Physiol 1986; 250: G7-8.

22 Schultz SG. Cellular models of epithelial ion transport. In: Adreoli TE, Hoffman JF, Fanestil DD, Schultz SG, eds. Physiology of membrane disorders. New York: Plenum Publishing Corporation, 1986: 519-34.

23 Powell DW. Ion and water transport in the intestine. In: Andreoli TE, Hoffman JF, Fanestil DD, Schultz SG, eds. Physiology of membrane disorders. New York: Plenum Publishing Corporation, 1986: 559-96.

24 DeRubertis FR, Craven PA. Early alterations in rat colonic mucosal nucleotide metabolism and protein kinase activity induced by 1,2-dimethylhydrazine. Cancer Res 1980; 40: 4589-98.

25 Craven PA, DeRubertis FR. Cyclic nucleotide metabolism of rat colonic epithelial cells with different proliferative activities. Biochim Biophys Acta 1981; 676: 155-69. 
26 Craven PA, Saito R, DeRubertis FR. Role of local prostaglandin synthesis in the modulation of proliferative activity of rat colonic epithelium. J Clin Invest 1983; 72: 1365-75.

27 Fernandez-Moreno MD, Diaz-Juarez JL, Arilla E, Prieto JC. Effect of resection of small intestine on the interaction of vasoactive intestinal peptide with rat colonic epithelial cells. Horm Metabol Res 1985; 17: 289-92.

28 Dietschy JM, Siperstein MD. Cholesterol synthesis by the gastrointestinal tract: localization and mechanisms of control. J Clin Invest 1965; 44: 1311-27.

29 Johnson LR, Guthrie PD. Mucosal DNA synthesis: A short term index of the trophic action of gastrin. Gastroenterology 1974; 67: 453-9.

30 McPherson JM, Whitehouse S, Walsh DA. Possibility of shape conformers of the protein inhibitor of cyclic adenosine monophosphate-dependent protein kinase. Biochemistry 1979; 18: 4835-45.

31 Lowry $\mathrm{OH}$, Rosebrough NJ, Farr AL, Randall RJ. Protein measurement with folin phenol reagent. J Biol Chem 1951; 193; 265-75.

32 Burton K. A study of the conditions and mechanism of the diphenylamine reaction for colorimetric estimation of deoxyribonucleic acid. Biochem J 1956; 62: 315-23.

33 Kikuchi K, Hirai R, Mitsui H, Kiuchi Y, Tsuiki S. Casein and histone kinases of rat ascites hepatoma as compared to those of rat liver. Gann 1985; 76: 1154-61.

34 Cochet C, Job D, Pirollet F, Chambaz EM. Adenosine 3',5'-monophosphate-independent protein kinase activities in the bovine adrenal cortex cytosol. Endocrinology 1980; 106: 750-7.

35 Schwartz B, Israeli V, Guberman R, Fraser GM, Krawiec J, Lamprecht SA. Pentagastrin enhances ornithine decarboxylase activity in rat colonic epithelium [Abstract). Gastroenterology 1986; 90: 1623.

36 Luk GD, Baylin SB. Polyamines and intestinal growthincreased polyamine biosynthesis after jejunectomy. Am J Physiol 1983; 245: G656-60.

37 Seidel ER, Haddox MK, Johnson LR. Polyamines in the response to intestinal obstruction. Am J Physiol 1984; 246: G649-53.

38 Mezzetti G, Moruzzi M, Piccinini G, Monti MG, Barbiroli B. Modulation of cyclic-independent protein kinase from chick intestine by naturally occurring polyamines and mucopolysaccharides. Mol Cell Biochem 1986; 70: 141-9.

39 Cho-Chung YS. Cyclic AMP and its receptor protein in tumor growth regulation in vivo. J Cyclic Nucleotide Res 1980; 6: 163-77.
40 Friedman DL. Regulation of the cell cycle and cellular proliferation by cyclic nucleotides. In: Kebabian JW, Nathanson JA, eds. Handbook of experimental pharmacology. Berlin: Springer-Verlag, 1982: 151-88.

41 Gottesman MM, Fleischmann RD. The role of cAMP in regulating tumor cell growth. In: Varmus $\mathrm{H}$, Bishop JM, eds. Cancer Surveys. Biochemical mechanisms of oncogene activity: proteins encoded by oncogenes. Oxford: Oxford University Press, 1986; 5: 291-308.

42 Lipkin M. Phase 1 and phase 2 proliferative lesions of colonic epithelial cells in diseases leading to colonic cancer. Cancer 1974; 34 [suppl]: 878-88.

43 Lipkin M. Proliferation and differentiation of gastrointestinal cells in health and disease. In: Green $M$, Greene HL, eds. The role of the gastrointestinal tract in nutrient delivery. London: Academic Press, 1984: 17-37.

44 Lamprecht SA, Schwartz B, Guberman R, Fraser GM, Krawiec J. Altered distribution of growth-related enzymes in rat colonic epithelium during chemical carcinogenesis [Abstract]. Bat Sheva seminar on tumor malignancy: pathogenesis and prevention of tumor dissemination. Bat-Sheva Seminar, Rehovot-Eilat, Israel, Aug 1987.

45 Elias L, Li AP, Longmire J. Cyclic adenosine $3^{\prime}: 5^{\prime}$ monophosphate-dependent and -independent protein kinase in acute myeloblastic leukemia. Cancer Res 1981; 41: 2182-8.

46 Pena JM, Itarte E, Domingo A, Cusso R. Cyclic adenosine $3^{\prime}: 5^{\prime}$-monophosphate-dependent and -independent protein kinases in human leukemic cells. Cancer Res 1983; 43: 1172-5.

47 Prowald K, Fisher H, Issinger O-G. Enhanced casein kinase II activity in human tumour cell cultures. FEBS Lett 1984; 176: 479-83.

48 Bishop JM. Viral oncogenes. Cell 1985; 42: 23-38.

49 Varmus $\mathbf{H}$, Bishop JM. Introduction. In: Varmus $\mathbf{H}$, Bishop JM, eds. Cancer surveys: Biochemical mechanisms of oncogene activity: Protein encoded by oncogenes. Oxford: Oxford University Press, 1986; 5: 153-8.

50 Heldin C-H, Westermark B. Growth factors: mechanism of action and relation to oncogenes. Cell 1985; 37 : 9-20.

51 Nakajo S, Shinkawa K, Shimizu T, Nakaya K, Nakamura Y. Purification and characterization of two cyclic AMP-independent protein kinases from AH-66 hepatoma ascites cells. J Biochem (Jpn) 1984; 96: 1575-85.

52 Nakaya K, Shinkawa K, Nakajo S, Nakamura Y. Phosphorylation of isolated plasma membranes of AH-66 hepatoma ascites cells by casein kinase I. Biochem Biophys Res Commun 1986; 138: 95-100. 